\title{
Late Cretaceous Biostratigraphy Planktonic Foraminifera of the Farokhi Formation, Iran
}

\author{
Mohsen Allameh $^{1 *}$, Reihane Rezayi Yazdi Nejad ${ }^{2}$ \\ ${ }^{1}$ Department of Geology, Mashhad Branch, Islamic Azad University, Mashhad, Iran \\ ${ }^{2}$ Stratigraphy \& Paleontology, Department of Geology, Mashhad Branch, Islamic Azad University, Mashhad, Iran \\ Email: *allameh0277@mshdiau.ac.ir, rryn67@yahoo.com
}

How to cite this paper: Allameh, M. and Nejad, R.R.Y. (2017) Late Cretaceous Biostratigraphy Planktonic Foraminifera of the Farokhi Formation, Iran. Open Journal of Geology, 7, 320-334.

https://doi.org/10.4236/ojg.2017.73022

Received: July 18, 2016

Accepted: March 21, 2017

Published: March 24, 2017

Copyright ( 92017 by authors and Scientific Research Publishing Inc. This work is licensed under the Creative Commons Attribution International License (CC BY 4.0).

http://creativecommons.org/licenses/by/4.0/

cC) (i) Open Access

\begin{abstract}
The Farokhi Formation is one of the informal Central Iran formations, which is located in the NW Tabas township. The Tabas area is a part of the Central Iran sedimentary basin which is located in the Yazd Province. The Farokhi stratigraphic section is located $7 \mathrm{~km}$ northwest from Farokhi village $\left(33^{\circ} 54^{\prime}\right.$ $9 " \mathrm{~N}$ and $54^{\circ} 52^{\prime} 48^{\prime \prime} \mathrm{E}$ ). The Bazyab, Debarso, Haftoman and Choopanan formations are well-exposed in the studied area. In this study, the Farokhi Formation is investigated in the Farokhi stratigraphic section with regard to planktonic foraminifera. The Farokhi Formation is mainly composed of thickbedded limestones with ammonoids, thin-bedded limestone with silicified echinoids and ichnofossils, marls with nodular cherts, spherical corals and bivalves. Biostratigraphy of the Farokhi Formation at type section has been concentrated in view of planktonic foraminifera. Thickness of this formation is 251 meters. The lower and upper contacts of studied formation with Haftoman and Choopanan formations are respectively conform and inconsistent. In view of late research, it has been identified that 28 planktonic foraminifera species have a place with 9 genera in edge of 6 biozones, for example: 1) Globotruncanita elevata Partial Range Zone. 2) Globotruncana ventricosa Interval Zone. 3) Globotruncanita stuartiformis Partial Range Zone. 4) Globotruncana aegyptiaca Interval Zone. 5) Gansserina gansseri Interval Zone. 6) Contu-sotruncana contusa Interval Zone. Finally based on this research, Early Campanian-Late Maastrichtian ages for the Farokhi Formation at type locality have been determined.
\end{abstract}

\section{Keywords}

Central Iran, Farokhi Formation, Biostratigraphy, Planktonic Foraminifera

\section{Introduction}

Central Iran continents have been divided into three parts such as Loot, Tabas 
and Yazd from east toward the west [1] [2]. The Farokhi Formation has been consisted of light grey limestone with chert and some echinoids and bivalves with high frequency. Lower parts of this formation were composed of marl and sandstone with 45 to 120 meters thickness.

This formation has out crop in Tabas Province. The studied section was placed at the west of Farokhi village. Farokhi Formation at type section has 65 180 meters thickness with light gray lime stone and chert with echinoids and bivalves with the high frequency and also based on brachiopoda, bivalves and echinoids, Late Senonian-Danian ages have been detected. [3] [4] studied Echinoids in Farokhi Formation and introduced Echinocorys ex.gr scutata. [5], for the first time studied Dinocyst in the Farrokhi Formation. Also [6] investigated Farokhi Formation at khoor section, based on planktonic foraminifera and proposed Early-Late Maastrichtian.

[7] has found Porosphaera globularis (kind of sponge). [8], based on benthic and planktonic foraminifera proposed Early Maastrichtian-Paleocene for the mentioned formation. [9] proposed Late Senonian-Paleocene for the studied formation based on Brachiopoda and Echinoids.

\section{Geological Setting}

The Tabas area is a part of the Central Iran sedimentary basin which is located in the Yazd Province. The Farokhi stratigraphic section is located $7 \mathrm{~km}$ northwest from Farokhi village ( $33^{\circ} 54^{\prime} 9^{\prime \prime} \mathrm{N}$ and $\left.54^{\circ} 52^{\prime} 48^{\prime \prime} \mathrm{E}\right)$. The Bazyab, Debarso, Haftoman and Choopanan formations are well-exposed in the studied area. In this study, the Farokhi Formation is investigated in the Farrokhi stratigraphic section with regard to echinoids (Figure 1). The Farokhi Formation is mainly composed of thick-bedded limestones with Ammonoids, thin-bedded limestone with silicified echinoids and ichnofossils, marls with nodular cherts, spherical corals and bivalves.

\section{Method}

Totally twenty three samples were collected from studied area .Depending on their lithology, the samples were washed in two methods. The shale and marl samples were put in $\mathrm{H}_{2} \mathrm{O}_{2} 10 \%$ for a day after being crushed into small pieces. The re-

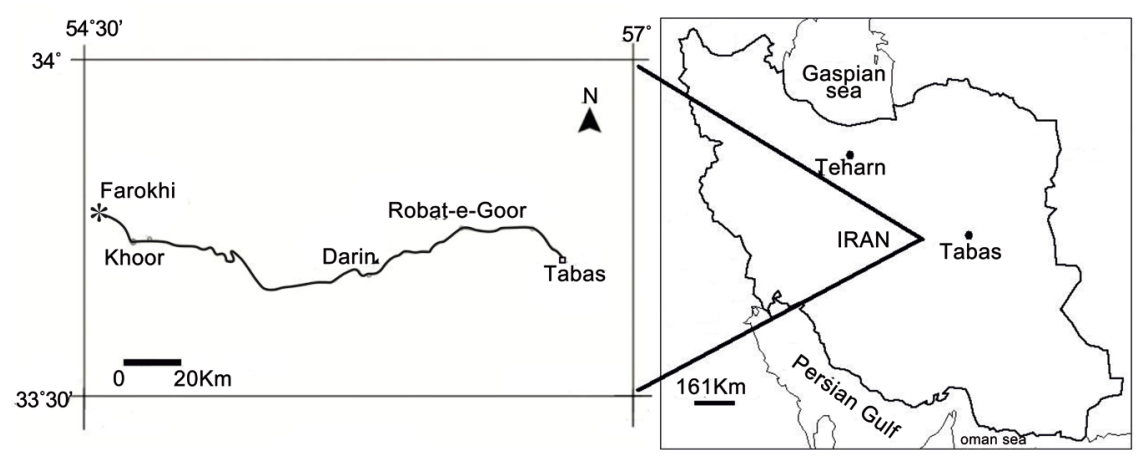

Figure 1. Location of the studied section in NE Iran. 
sidues were then washed with water on the screeners assigned with 125 and 63 $\mu \mathrm{m}$ meshes [10].

Limestones were grid and boiled in $\mathrm{Na}_{2} \mathrm{So}_{4}$ solution then washed with water on the screeners assigned with the above mentioned meshes [11].

First, all of samples were chopped to a crashed sediment and then took in $\mathrm{H}_{2} \mathrm{O}_{2}$ (10\% molar) for 12 hours and then washed all of these sediments on the various number of sieves, respectively $63 \mu \mathrm{m}$ and $125 \mu \mathrm{m}$ (reframe). Finally, for separation of sediment and fossils, all of washed samples stayed in Ultrasonic Cleaner for $15 \mathrm{~min}$ and then they were washed again.

Ultimately, all sample residues remaining on mentioned sieves were studied and picked and then taken picture by Scanning Electron Microscope (SEM) in central laboratory of Ferdowsi University of Mashhad. All of SEM pictures in this manuscript were arranged in 4 plates as Appendix (Plates 1-4).

\section{Lithostratigraphy of the Farokhi Formation at Type Section}

Lithostratigraphy of the Farokhi Formation is in the study area. The upper and lower boundaries of the Farokhi Formation in the studied stratigraphic section are not observable because of the wide-spreading of formation in the area. From the lithological point of view, the Farokhi Formation in the studied area is mainly composed of the units as followed (Figure 2):

Thick-bedded, pinky limestone with fossil debris in some parts $(50.50 \mathrm{~m})$; Thin-bedded limestone with great amount of cherty echinoids and ichnofossils $(18.50 \mathrm{~m})$; Marls with great amount of cherty echinoids, nodular cherts, spherical corals and bivalves $(22.50 \mathrm{~m})$; Marls with reworked spherical corals $(1.50 \mathrm{~m})$. Marls with intercalations of shales and limestones with echinoids, spherical corals, colonial corals and bivalves $(5.50 \mathrm{~m})$; Marls $(44 \mathrm{~m})$; Marls without macrofauna, with secondary oxideveins and small joints $(11 \mathrm{~m})$; Marls $(29.50 \mathrm{~m})$; Marly limestone and limy marls $(7.50 \mathrm{~m})$; Hardened marls with coatings of iron oxide and no macrofauna $(6 \mathrm{~m})$; Dark limestone without any macrofauna (4.50 $\mathrm{m})$; Limestones with ichnofossils, ammonoids and spherical corals (9.50 m); Pale limestones with ichnofossils and echinoids $(5.50 \mathrm{~m})$; Thin-bedded limestones with cherts and echinoids $(11 \mathrm{~m})$; Thin-bedded limestones with ichnofossils (4 $\mathrm{m})$; Limestones with echinoids ( $9 \mathrm{~m}$ ); Limestones with ichnofossils and partially compressed echinids (11 m); Limestones without any macrofauna $(4 \mathrm{~m})$.

\section{Conclusion}

Foraminifera, Latin, meaning hole bearers, (informally called "forams") are members of a phylum or class of amoeboid protists characterized by streaming granular ectoplasm that among other things is used for catching food, and commonly by an external shell or "test" made of various materials and constructed in diverse forms. All but perhaps a very few are aquatic and most are marine, the majority of which live on or within the seafloor sediment (i.e., are benthic) while a smaller variety are floaters in the water column at various depths (i.e., are 


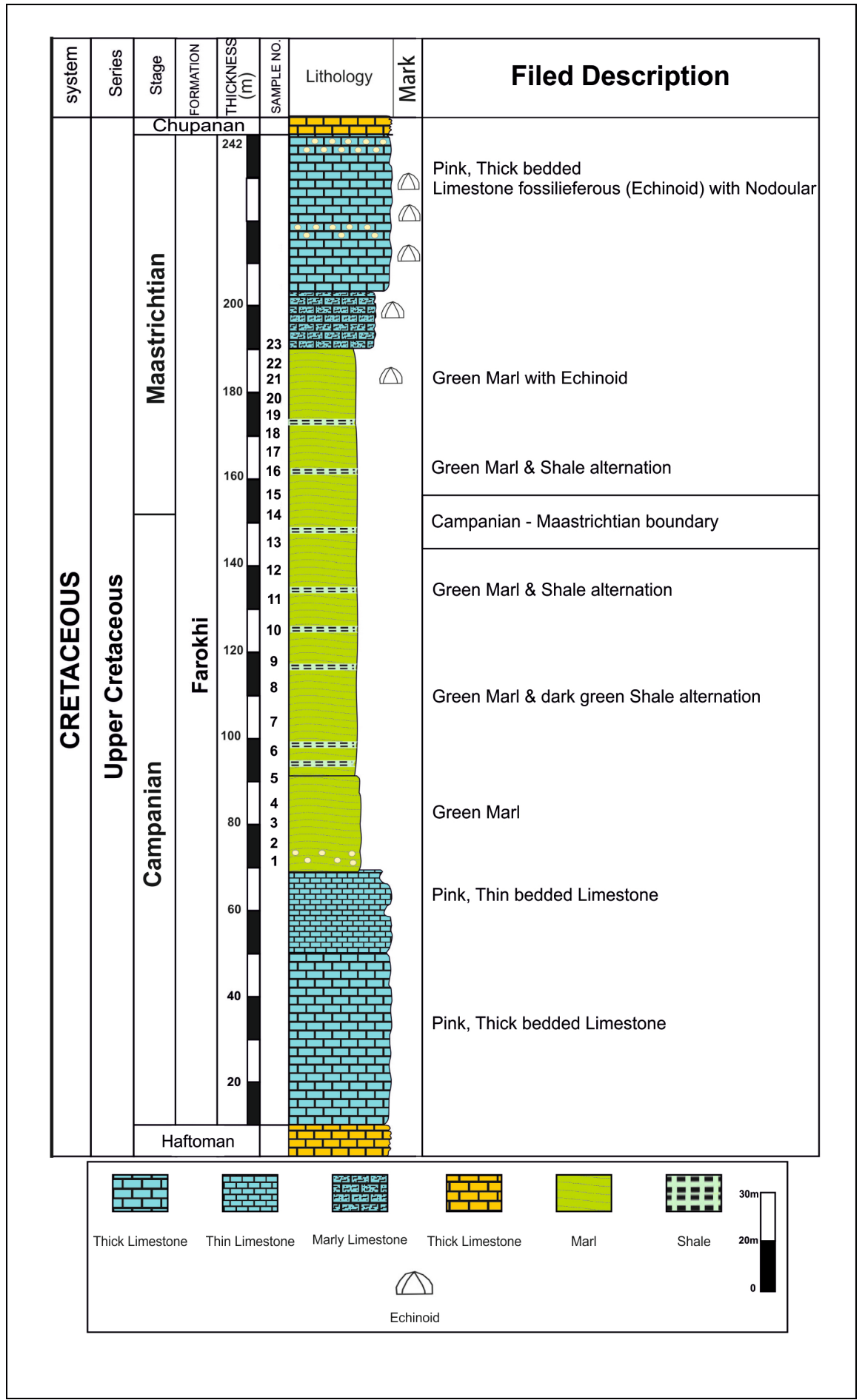

Figure 2. Stratigraphic column of the Farokhi Formation in the studied area.

planktonic). A few are known from freshwater or brackish conditions and some soil species have been identified through molecular analysis of small subunit ribosomal DNA. Dying planktonic Foraminifera continuously rain down on the sea floor in vast numbers, their mineralized tests preserved as fossils in the accumulating sediment. Beginning in the 1960s, and largely under the auspices of the Deep Sea Drilling, Ocean Drilling, and International Ocean Drilling Pro- 
grammers, as well as for the purposes of oil exploration, advanced deep-sea drilling techniques have been bringing up sediment cores bearing Foraminifera fossils. The effectively unlimited supply of these fossil tests and the relatively high-precision age-control models available for cores has produced an exceptionally high-quality planktonic Foraminifera fossil record dating back to the mid-Jurassic, and presents an unparalleled record for scientists testing and documenting the evolutionary process. The exceptional quality of the fossil record has allowed an impressively detailed picture of species inter-relationships to be developed on the basis of fossils, in many cases subsequently validated independently through molecular genetic studies on extant specimens.

\section{Biozonation of Farokhi Formation}

Diverse planktonic Foraminifera possessing wide stratigraphic range occur in abundance in most samples of the Farokhi Formation in the studied area. Nine genera and twenty eight species of planktonic Foraminifera were recognized. The zonal scheme presented here consists of 6 zones on the basis of the stratigraphic distribution of planktonic Foraminifera recognized in isolated specimens (Figure 3). Foraminiferal taxonomy and nomenclature of the identified taxa are followed after [12]-[17]. The planktonic foraminiferal zonation here used is compared in Figure 4 with other Tethyan biozonations [18]-[29]. This zonation is similar to that of Premoli-Silva and Verga, 2004.

Some of planktonic foraminifera that have been found at mentioned formation are as follows:

Abathomphalus sp., Contusotruncana contusa, Contusotruncana patelliformis, Dicarinella sp. Gansserina gansseri, Globigerinelloides sp., Globotruncana aegyptiaca, Globotruncana arca, Globotruncana bulloides, Globotruncana elevata, Globotruncana fornicata, Globotruncana lapparenti, Globotruncana linneiana, Globotruncana mariei, Globotruncana rugusa, Globotruncanita subspinosa, Globotruncana ventricosa, Globotruncanita atlantica, Globotruncanita conica, Globotruncanita stuarti, Globotruncanita stuartiformis, Marginotruncana pseudolinneiana, Marginotruncana sp.

The biozonation is as follows:

\subsection{Globotruncanita Elevate Partial Range Zone}

Definition: Interval from last occurrence of Dicarinella asymetrica to first occurrence of Globotruncana ventricosa.

Age: Early Campanian.

Partial range of the nominate taxon from the last appearance of Dicarinella asymetrica to the first appearance of Globotruncana ventricosa defines the zone. This Biozone was defined for the first time by Postuma (1971). The biozone is 11.5 meter thick and consists of grey dark, greyish to green and blue shale.

Important fossils recognized in this zone include:

Archaeoglobigerina blowi, Archeoglobigerina cretacea, Contusotruncana fornicata, Contusotruncana patelliformis, Globigerinelloides bollii, Globigerinel- 


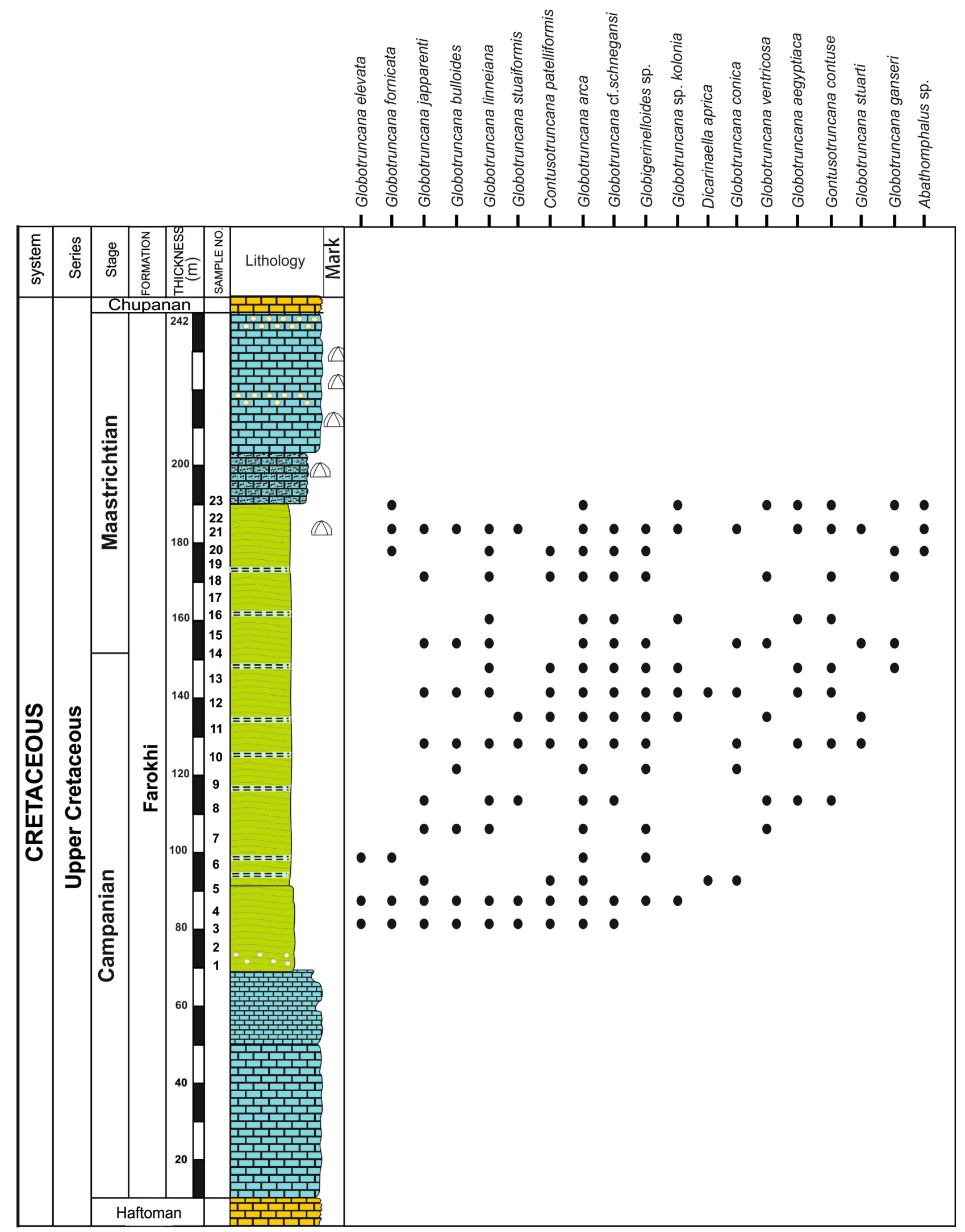

Figure 3. Distribution and planktonic foraminiferal zonation of the Farokhi Formation at type section. 


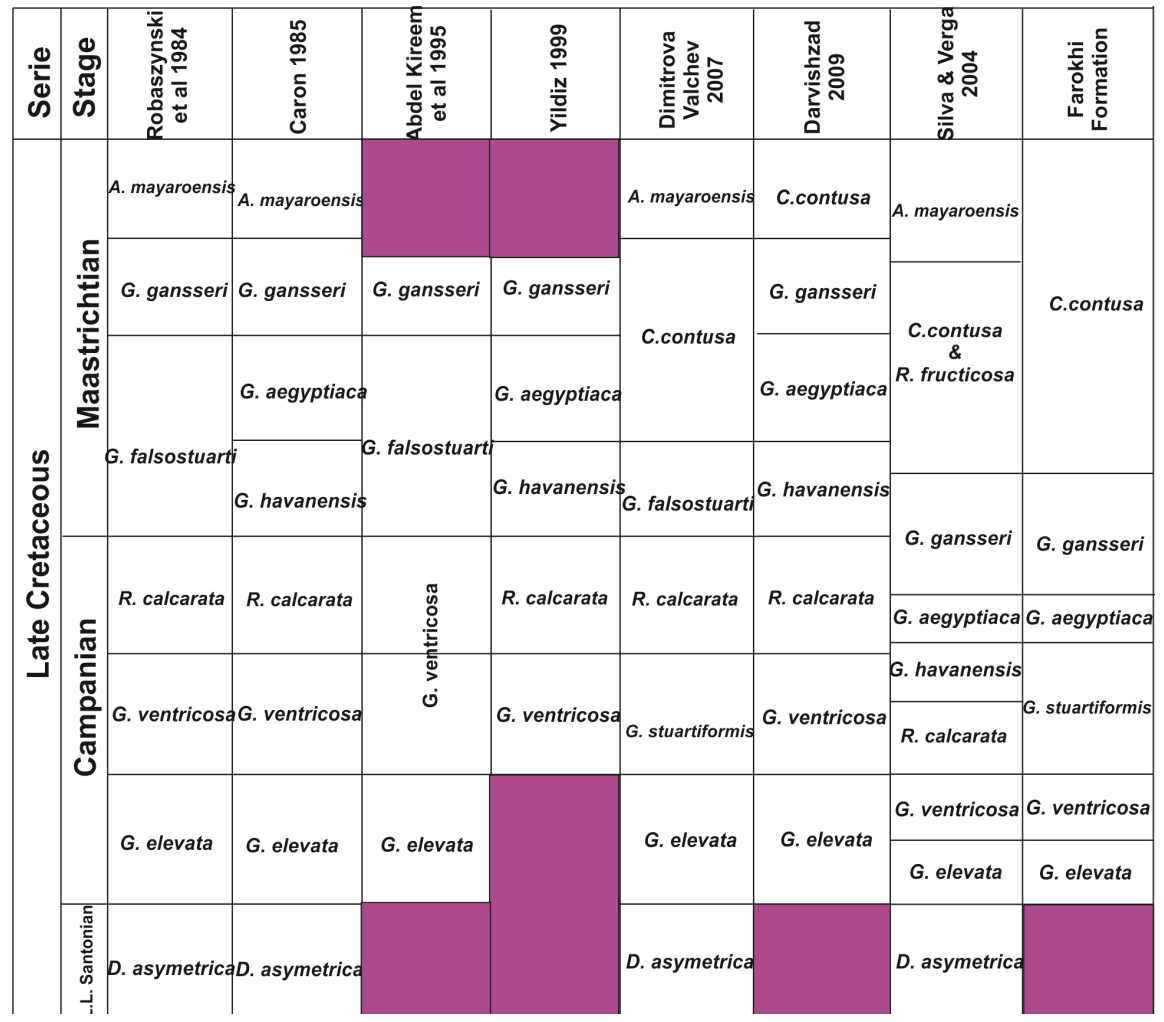

Figure 4. Correlation of the proposed biostratigraphic zonal scheme at this study with other accepted standard biozones of other parts of the world.

loides prairiehillensis, Globigerinelloides multispina, Globigerinelloides ultramicra, Globotruncana arca, Globotruncana bulloides, Globotruncana lapparenti, Globotruncana linneiana, Globotruncana mariei, Globotruncana orientalis, Globotruncanita stuartiformis, Heterohelix globulosa, Heterohelix papula, Heterohelix punctulata, Heterohelix striata, Laeviheterohelix pulchera, Laeviheterohelix turgida, Pseudotextularia uttalli.

\subsection{Globotruncana ventricosa Interval Zone}

Definition: Interval from first occurrence of Globotruncana ventricosa to first occurrence of Radotruncana calcarata.

Age: Middle Campanian.

The biozone is 24 meter thick and it consists of grey to green shale, grey to light blue marl, and grey to dark blue marl. This zone was defined by Dalbiez, (1955) as the range of the nominate taxon between its first appearance to the first occurrence of Radotruncana calcarata.

Main fossils are recognized in this zone such as:

Archaeoglobigerina blowi, Archeoglobigerina cretacea, Contusotruncana fornicata, Contusotruncana patelliformis, Globigerinelloides prairiehillensis, Globigerinelloides ultramicra, Globotruncana arca, Globotruncana bulloides, Globotruncana hilli, Globotruncana lapparenti, Globotruncana linneiana, Globotruncana mariei, Globotruncana orientalis, Globotruncanita elevata, Globotruncanita stuartiformis, Heterohelix globulosa, Heterohelix punctulata, Heterohelix striata, 
Laeviheterohelix pulchera, Pseudotextularia nuttalli.

\subsection{Globotruncanita stuartiformis Partial-Range Zone}

Age: Middle Campanian.

Partial range of the nominate taxon from the last appearance of Globotruncana ventricosa to the first appearance of Globotruncana aegyptiaca defines the zone. This Biozone was defined for the first time by [30]. The biozone is 22.5 meter thick and consists of grey dark, greyish to green and blue shale.

Main fossils are recognized in this zone such as:

Globotruncanita stuartiformis (Dalbiez), Archaeoglobigerina blowi Pessagno, Archaeoglobigerina cretacea (d'Orbigny), Contusotruncana fornicata (Plummer), Heterohelix planata (Cushman), Macroglobigerinelloides bollii (Pessagno), Globotruncana falsostuarti Sigal, Globotruncana orientalis El-Naggar, Globotruncana mariei Banner \& Blow, Globotruncanella havanensis (Voorwijk), Globotruncana linneiana (d'Orbigny), Globotruncana ventricosa (White), Globotruncanita stuartiformis (Dalbiez), Globotruncanita stuarti (de Lapparent), Globotruncana arca (Cushman), Globotruncana bulloides Volger, Globotruncana lapparenti Brotzen, Pseudotextularia nuttalli (Voorwijk), Rugoglobigerina rugosa (Plummer).

\subsection{Globotruncana aegyptiaca Interval Zone}

Definition: Interval from first occurrence of Globotruncana aegyptica to first occurrence of Ganserina gansseri.

Age: late Campanian.

The biozone is 15.5 meter thick and it consists of grey to light green shale and grey to light green silty shale. The range of this biozone was introduced by Bronnimann in 1952 from the first occurrence of Globotruncana aegyptica to first occurrence of Gansserina gansseri. This biozone has late Campanian age.

Main fossils are recognized in this zone are:

Globotruncana aegyptiaca Caron, Contusotruncana fornicataa (Plummer), Heterohelix planata (Cushman), Heterohelix globulosa (Ehrenberg), Muricohedbergella monmouthensis (Olsson), Globotruncana arca (Cushman), Globotruncana bulloides Volger, Globotruncana falsostuarti Sigal, Globotruncana ventricosa (White), Globotruncanita stuartiformis (Dalbiez), Globotruncana linneiana (d'Orbigny), Globotruncana lapparenti Brotzen, Globotruncana orientalis El-Naggar, Globotruncana mariei Banner \& Blow, Globotruncanita stuarti (de Lapparent), Globotruncanella havanensis (Voorwijk), Pseudotextularia nuttalli (Voorwijk).

\subsection{Gansserina gansseri Interval Zone of Premoli Silva \& Bolli} (1973)

Definition: Interval from first occurrence of Ganserina gansseri to first occurrence of Contusotruncana contusa.

Age: late Campanian-Early Maastrichtian.

The biozone is 14 meter thick and it consists of grey to light green shale and 
grey to light green silty shale. The range of this biozone was introduced by Bronnimann in 1952 from the first occurrence of Ganserina gansserito and first occurrence of Contusotruncana contusa. This biozone has late Campanian age.

Main fossils are recognized in this zone are:

Gansserina gansseri (Bolli), Archaeoglobigerina blowi Pessagno, Globotruncana falsostuarti Sigal, Contusotruncana fornicataa (Plummer), Contusotruncana patelliformis (Gandolfi), Contusotruncana plicata (White), Contusotruncana plummera (Gandolfi), Heterohelix punctulata (Cushman), Heterohelix globulosa (Ehrenberg), Muricohedbergella monmouthensis (Olson), Globotruncana orientalis El-Naggar, Globotruncana mariei Banner \& Blow, Globotruncana lapparenti Brotzen, Globotruncana arca (Cushman), Globotruncana bulloides Volger, Globotruncana ventricosa (White), Globotruncanita stuartiformis (Dalbiez), Globotruncanita stuarti (de Lapparent), Rugoglobigerina rugosa (Plummer).

\subsection{Contusotruncana contusa Interval Zone (Premoli Silva \& Bolli, 1973)}

Definition: Interval from first occurrence of Contusotruncana contusato and first occurrence of Abathomphalus mayaroensis

Age: Early-Late Maastrichtian.

The biozone is 7.5 meter thick and it consists of grey to light green shale and grey to light green silty shale. The range of this biozone was introduced by Bronnimann in 1952 from the first occurrence of Ganserina gansserito first occurrence of Contusotruncana contusa. This biozone has late Campanian age.

Main fossils are recognized in this zone are:

Contusotruncaca contusa (Cushman), Archaeoglobigerina blowi Pessagno, Contusotruncana fornicata (Plummer), Gansserina gansseri (Bolli), Globotruncana orientalis El-Naggar, Globotruncana mariei Banner \& Blow, Globotruncana lapparenti Brotzen, Globotruncana arca (Cushman), Globotruncana bulloides Volger, Globotruncana ventricosa (White), Globotruncanita stuartiformis (Dalbiez), Globotruncanita stuarti (de Lapparent), Globotruncanella havanensis (Voorwijk), Pseudotextularia elegans (Rzehak), Pseudotextularia intermedia deKlasz, Pseudotextularia nuttalli (Voorwijk), Rugoglobigerina rugosa (Plummer).

At last in view of late research, Early Campanian-Late Maastrichtian ages for this formation have been recorded.

\section{Result}

Farokhi Formation has been studied at type section in Central of Iran. Twenty eight planktonic foraminifer species belonging to 8 genera in frame of 6 biozones have been recorded as below:

1) Globotruncanita elevata Partial Range Zone. 2) Globotruncana ventricosa Interval Zone. 3) Globotruncanita stuartiformis Partial Range Zone. 4) Globotruncana aegyptiaca Interval Zone. 5) Gansserina gansseri Interval Zone. 6) Contusotruncana contusa Interval Zone. 
Based on this research Early Campanian-Maastrichtian ages were detected of mentioned studied section. Finally all of realized biozones in this research have been compared with main Tyetyan biozonation scheme in the world and all of zones which were identified for Farokhi Formation at type section resembles with [17] biozonation.

\section{References}

[1] Nadimi, A. (2007) Evolution of the Central Iranian Basement. Gondwana Research, 12, 324-333. https://doi.org/10.1016/j.gr.2006.10.012

[2] Nazemi (1998) Plate Tectonic of TAbas Area with Focus on the Qory Chee Area Plate Tectonic (South of Tabas). Msc Dissertation, Geological Survey of Iran, Tehran.

[3] Aghanabati (2002) Geology of Iran. Geological Survey of Iran, Tehran.

[4] Allameh, M. and Taherpour Khalil Abad, M. (2014) Systematic Interpretation of Silicified Specimens of Upper Cretaceous Echinocorys ex. gr. scutata (Leske, 1778), Farokhi Formation, Central Iran. Journal of Sciences, 25, 237-251.

[5] Torabian, B. and Allameh, M. (2011) First Introduced of Upper Cretaceous Dinocyst from the West of Farrokhi Village at Central of Iran. National Congress of Applied Geology in Basical Sciences. Azad University of Iran, Tehran.

[6] Seyf, H., Majidifard, M. and Mohtat, T. (2013) New Biostratigraphic Finding of the Farrokhi Formation in the South West of Khoor (Central Iran) Based of Planktonic Foraminifera. Thirty Second Symposium and First Specific International Earth Science.

[7] Wilmsen, M., Fürsich, F.T. and Majidifard, M.R., (2012) Porosphaera Globularis (Phillips, 1829) (Porifera, Calcarea) from the Maastrichtian of the Farrokhi Formation of Central Iran. Cretaceous Research, 33, 91-96.

https://doi.org/10.1016/j.cretres.2011.09.002

[8] Razmjooee, A. (2011) Lithostratigraphy and Biostratigraphy of the Farrokhi Formation at North Western of the Khoor. Msc Dissertation, Geological Survey of Iran, Tehran, $202 \mathrm{p}$.

[9] Aistov, L., Melnikov, B., Krivyakin, B., Morozov, L. and Kiristaev, V. (1984) Geology of the Khur Area (Central Iran). Explanatory Text of the Khur Quadrangle Map1: 250.000, V/O Technoexport Report 20, 1e130.

[10] Zepeda, M.A. (1998) Planktic Foraminifera Diversity, Equitability and Biostratigraphy of the Uppermost Campanian-Maastrichtian, ODP Leg122, Hole 762, Exmoth Plateau, NW Australia, Eastern Indian Ocean. Cretaceous Research, 19, 117- 152. https://doi.org/10.1006/cres.1997.0097

[11] Peryt, D. and Lamolda, M.A. (2002) Benthic Foraminifers from the Coniacian- Santonian Boundary Interval at Olazagutia, Spain. Meeting on the Coniacian-Santonian Boundary, Bilbao, 14-16 September 2002, 19.

[12] Postuma, J. (1971) Manual of Planktonic Foraminifera. Elsevier Publishing Company, Amsterdam, $420 \mathrm{p}$.

[13] Robaszynski, F., Caron, M., Gonzales Donoso, J.M. and Wonders, A. (1984) The European Working Group on Planktonic Foraminifera, 1984. Atlas of Late Cretaceous Globotruncanids Revue de Micropaleontologic, 26, 145-305.

[14] Loeblich, A.R. and Tappan, E. (1988) Foraminiferal Genera and Their Classification. Van Nostrand Reinhold Company, New York, 970 p. https://doi.org/10.1007/978-1-4899-5760-3

[15] Nishi, T. (2003) The First Putative Transmembrane Segment of Subunit c 
(Vma16p) of the Yeast V-ATPase Is Not Necessary for Function. The Journal of Biological Chemistry, 278, 5821-5827. https://doi.org/10.1074/jbc.M209875200

[16] Nederbragt, A. (1991) Late Cretaceous Biostratigraphy and Development of Heterohelicidae (Planktic Foraminifera). Micropaleontology, 37, 329-372.

[17] Premoli Silva, I. and Verga, D. (2004) Practical Manual of Cretaceous Planktonic Foraminifera, Course 3. In: Verga, D. and Rettori, R., Eds., International School on Planktonic Foraminifera: Universities of Perugia and Milano, Tipografiadi di Pontefelcino, Perugia, 283 p.

[18] Premoli-Silva, I. and Sliter, W.V. (1981) Cretaceous Planktonic Foraminifers from the Nauru Basin, Leg 61, Site 462 Western Equatorial Pacific. Initial Report. Deep Sea Drill Project, 61, 423-437. https://doi.org/10.2973/dsdp.proc.61.104.1981

[19] Bolli, H.M. (1957) The Genera Praeglobotruncana, Globotruncana, Rotalipora Abathomphalus in the Upper Cretaceous of Trinidad, B.W.I.U.S. Natural History $\mathrm{Mu}$ seum Bulletin, 215, 51-60.

[20] Pessagno, E.A. (1967) Upper Cretaceous Planktonic Foraminifera from the Western Gulf Coastal Plain. Palaeontographica Americana, 5, 259-441.

[21] Van Hinte, J.E. (1976) A Cretaceous Time Scale. Bulletin-American Association of Petroleum Geologists, 60, 498-516.

[22] Sigal, J. (1977) Essai du zonation du Cretace mediterraneenne an 1 aide des foraminiferes planctoniquess. Geologie Mediterraneenne, 4, 99-108.

[23] Wonders, A.A. (1980) Middle and Late Cretaceous planktonic Foraminifera of the Western Mediterranean Area. Utrecht Micropaleontology Bulletin, 24, 1-158.

[24] Caron, M. (1985) Cretaceous Planktik Foraminifera. In: Bolli, H.M., Saunders, J.B. and Perch Nielsen, K., Eds., Plankton Stratigraphy, Cambridge University Press, Cambridge, 17-86.

[25] Sliter, W.V. and Leckie, R.M. (1993) Cretaceous Planktonic Foraminifera in Sediments of the Ontong Java Plateau. Bulletin de la Societe Geologique de France, 166, 681-692.

[26] Robaszynski, F. and Caron, M. (1995) Foraminiferes Planctoniques du Cretace: Commentaire de la zonation Europe-Mediterranee. Bulletin de la Societe Geologique de France, 6, 681-692.

[27] Yildiz, A. and Ozdemir, Z. (1999) Biostratigraphic and Isotopic Data on the Coreklik Member of the Hekimhan Formation (Campanian-Maastrichtian) of SE Turkey and Palaeoenvironmental Significance. Cretaceous Research, 20, 107-117. https://doi.org/10.1006/cres.1998.0139

[28] Dimitrova, E. and Valchev, B. (2007) Attempt for Upper Cretaceous Planktic Foraminiferal Zonation of the Srednogoria and Eastern Balkan Zones (Bulgaria). Geologica Balcanica, 36, 55-63.

[29] Darvishzadeh, B. and Abdolalipour, S. (2009) Campanian and Maastrichtian Biostratigraphy and Paleoenvironment in Jorband Section, North of Iran. Journal of Sciences, 20, 23-39.

[30] Al-Mutwali, M.M., Al-Banna, N.Y. and Al-Ghrear, J.S. (2008) Microfacies and Sequences Stratigraphy of the Late Campanian Bekhme Formation in Dohuk Area, North Iraq. GeoArabia, 13, 39-54. 
Appendix

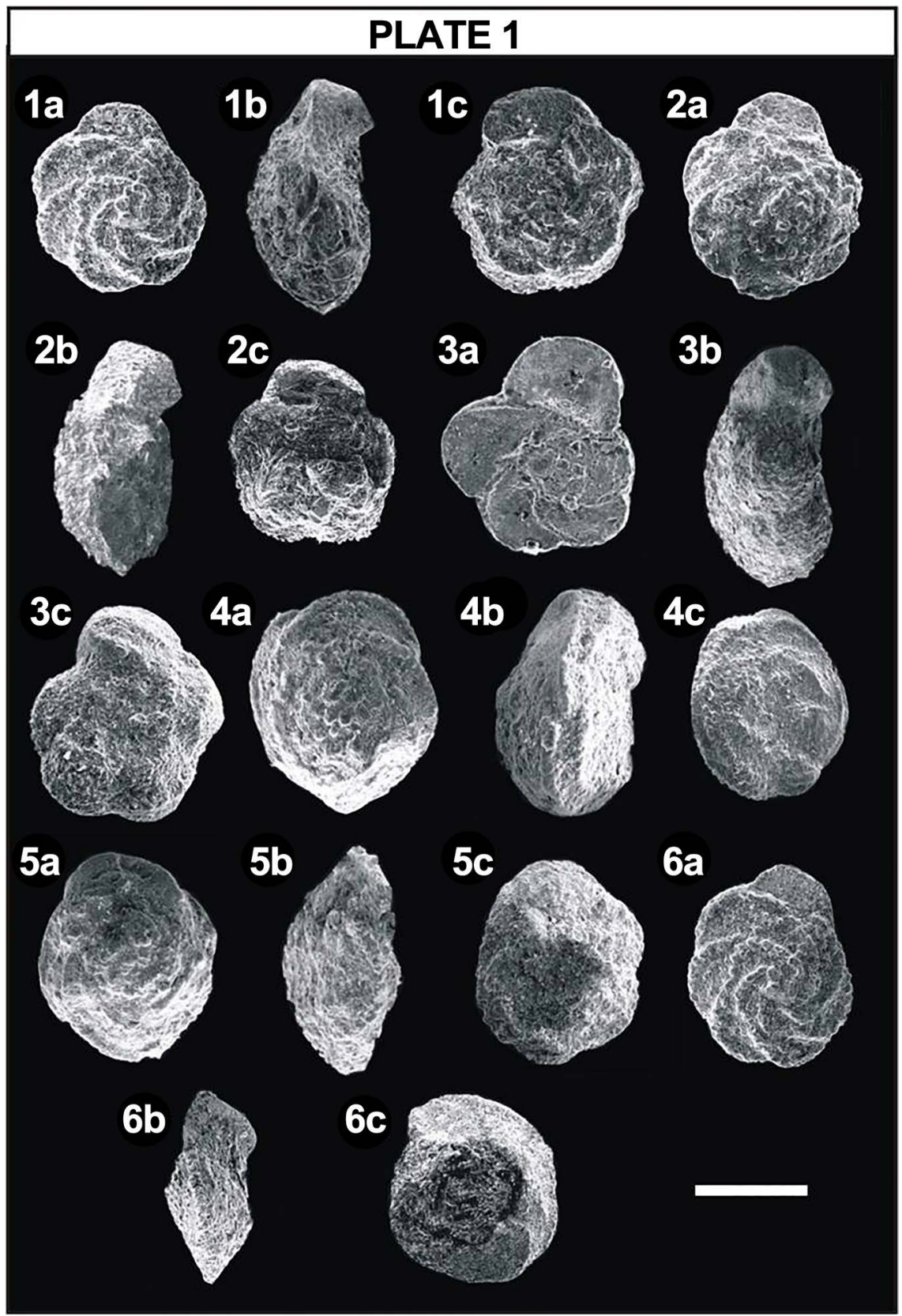

Plate 1. 1a, 1b and 1c: Globotruncana arca; 2a, 2b and 2c: Globotruncana cf.arca; 3a, 3b and 3c: Globotruncana cf. marie, 4a, 4b and 4c: Contusotruncana cf. fornicata; 5a, 5b and 5c: Contusotruncana cf. patelliformis, 6a, 6b and 6c: Globotruncanitaelevata. Scale bar represent 100 micrometers. 


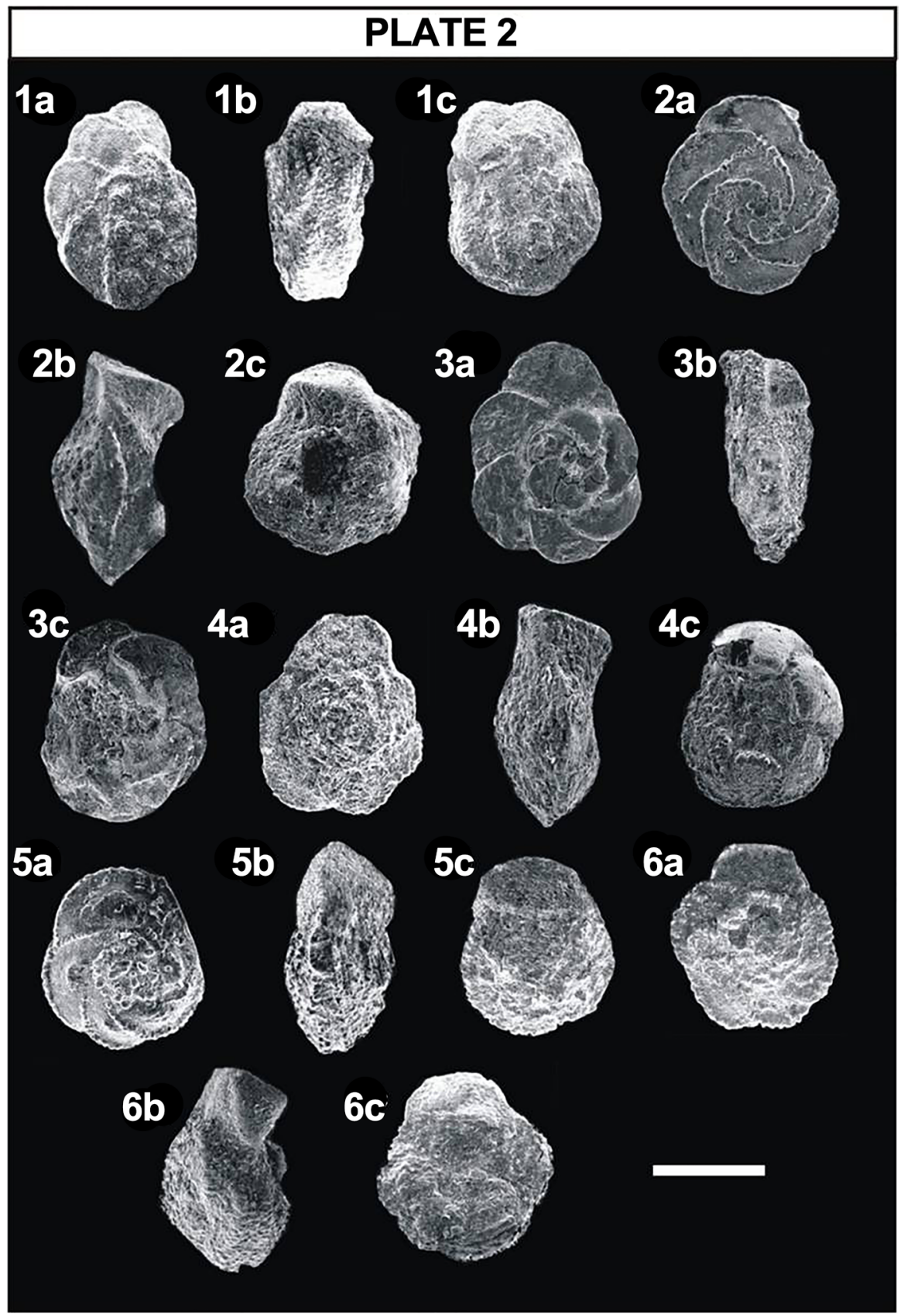

Plate 2. 1a, 1b and 1c: Globotruncana cf. ventricosa; 2a, 2b and 2c: Globotruncanitaelevata; 3a, $3 \mathrm{~b}$ and 3c: Globotruncana lapparent; 4a, 4b and 4c: Globotruncanita stuartiformis, 5a, 5b, and 5c: Globotruncana orientalis, 6a, 6b and 6c: Globotruncana oblique. Scale bar represent 100 micrometers. 


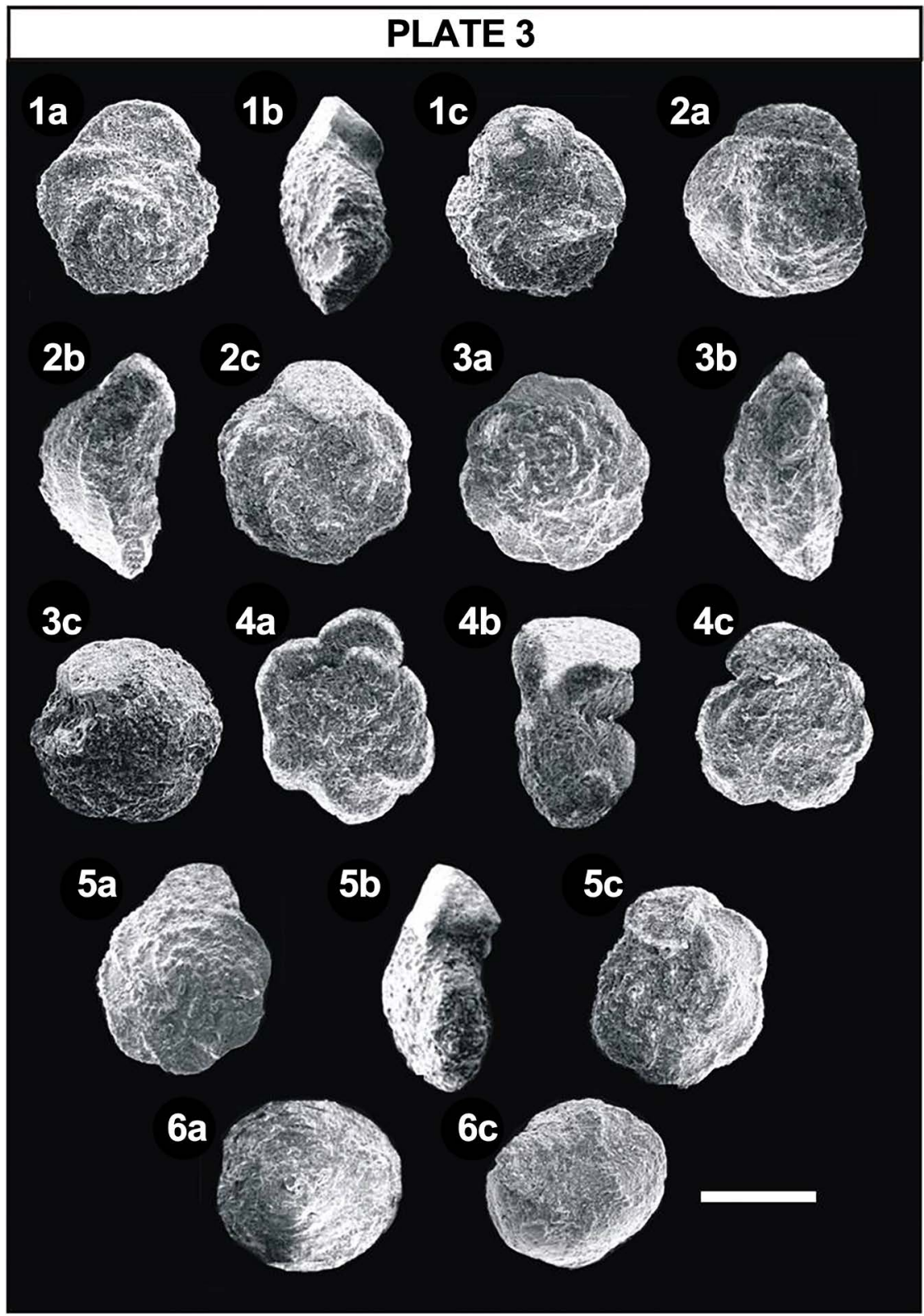

Plate 3. 1a, 1b and 1c: Globotruncana cf linneiana; 2a, 2b and 2c: Globotruncanaconica, 3a, 3b and 3c: Globotruncana of dupableie, 4a, 4b and 4c: Gansserina gansseri, 5a, 5b and 5c: Globotruncana cf. arca; 6a and 6c: Contusotruncana cf contusa. Scale bar represent 100 micrometer. 


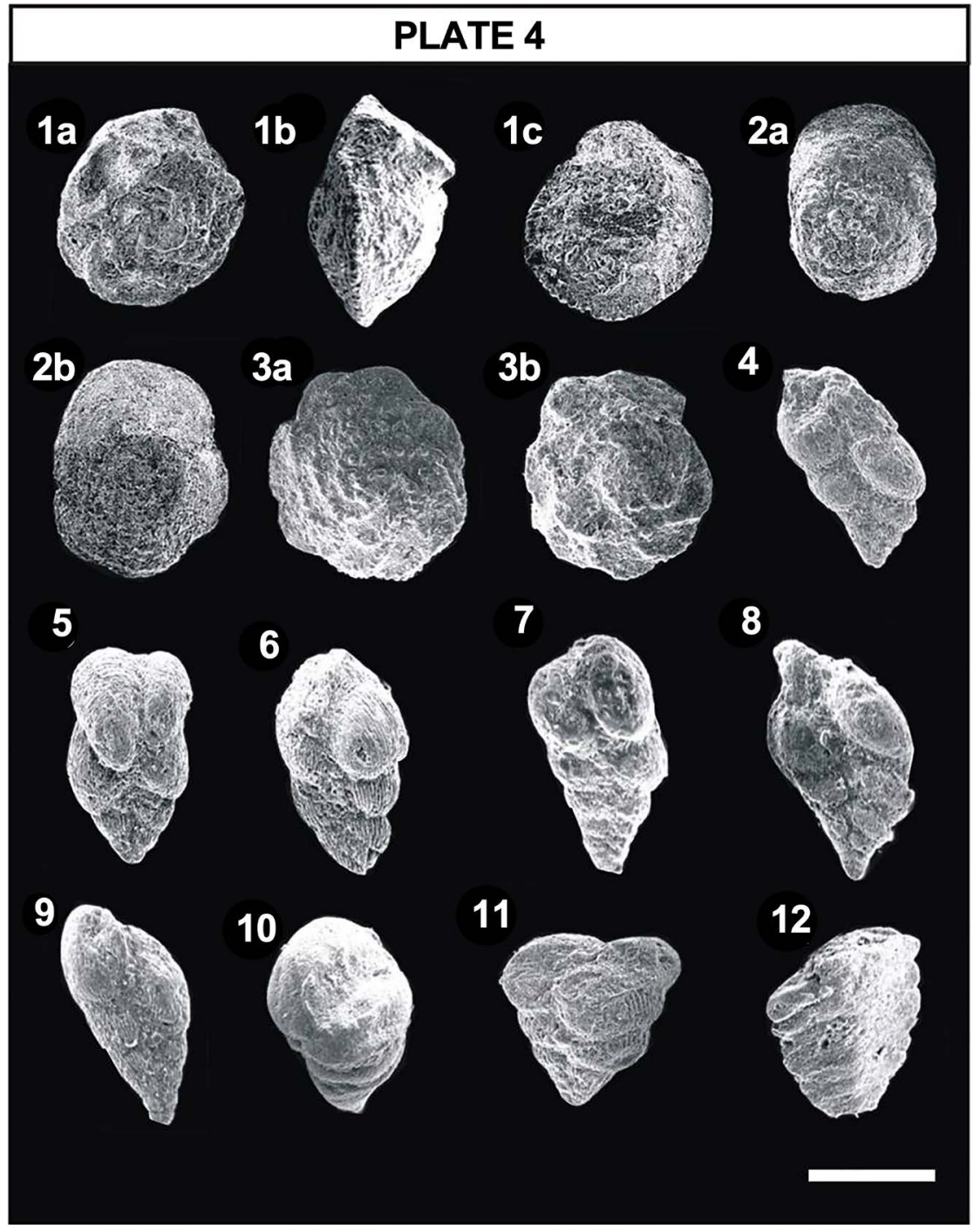

Plate 4. 1a, 1b and 1c: Globotruncanita stuart; 2a and 2b: Globotruncana aegyptiaca; 3a and 3b: Globotruncana sp; 4: Heterohelix globulosa; 5 and 6: Heterohelix striata; 7: Heterohelix moremani; 8: Laeviheterohelix pulchra; 9: Heterohelix reussi; 10: Pseudotextularia nuttalii, 11 and 12: Pseudotextularia elegans. Scale bar represent 100 micrometer. 
Submit or recommend next manuscript to SCIRP and we will provide best service for you:

Accepting pre-submission inquiries through Email, Facebook, LinkedIn, Twitter, etc. A wide selection of journals (inclusive of 9 subjects, more than 200 journals)

Providing 24-hour high-quality service

User-friendly online submission system

Fair and swift peer-review system

Efficient typesetting and proofreading procedure

Display of the result of downloads and visits, as well as the number of cited articles Maximum dissemination of your research work

Submit your manuscript at: http://papersubmission.scirp.org/

Or contact ojg@scirp.org 